The school works in close co-operation with the 10th Air Search and Rescue Squadron, which is called upon in cases of emergency to drop sledges, dog teams, and drivers by parachute.

It has been found that dog teams are more effective than either helicopter or "Weasel" for rescue work on land, and a number of sledge dogs are kept at the school; the drivers, almost without exception, are enlisted Eskimo holding ranks up to that of sergeant. With these facilities it is claimed that there is no part of Alaska in which rescue operations are impossible.

\title{
UNITED STATES AIR FORCE RESCUE FLIGHTS IN GREENLAND, 1947 AND 1948
}

[Summarized from information in the National Geographic Magazine, Vol. 96, No. 4, 1949, p. 525; The Times of 20 and 29 December 1948; Manchester Guardian of 21 December 1948: and New York Times of 29 December 1948.]

In February 1947 a United States B-29 aircraft, known as the Kee-Bird, was forced down in Daugaard-Jensens Land in north-west Greenland. A rescue aircraft, piloted by Lieutenant Bobby Joe Cavenar, U.S.A.A.F., was flown from Westover Air Force Base, Massachusetts. A landing was made beside the wrecked machine and the eleven stranded members of the crew were safely removed.

On 9 December 1948 a United States C-47 transport aircraft crashed on the Greenland ice cap some 230 miles south-east of Bluie West Eight (Søndre Stromfjord), $7800 \mathrm{ft}$. above sea-level. The stranded crew of seven built shelters with blocks of snow and communications were established by means of a wireless transmitter salvaged from the aircraft: supplies were dropped by parachute, but on 14 December a B-17 Flying Fortress, with a crew of two, crash-landed while attempting a rescue. Four days later a glider was dropped to the nine stranded men, and a transport aircraft made two unsuccessful attempts to snatch the heavily laden machine from the ice. The wheels of the glider were afterwards removed, and on the third attempt it was lifted clear of the ice. Unfortunately the tow rope parted almost immediately, but a safe landing was made and the five men on board escaped injury. At this time the temperature was $-40^{\circ} \mathrm{F} .\left(-40^{\circ} \mathrm{C}\right.$.). Later attempts to lift the glider also failed, and three more airmen were forced to join the stranded party. Finally, a ski-fitted C-47 flown by Lieutenant-Colonel Emil G. Beaudry and Lieutenant Charles W. Blackwell effected a landing on 28 December. The aircraft was fitted with jet-assisted take-off equipment to minimize the hazards of a long take-off from rough snow, and the twleve rescued airmen were taken to Bluie West Eight.

\section{IONOSPHERIC STATIONS IN CANADA}

[Based on notes in Arctic Circular, Vol. 1, No. 1, 1948, p. 3-4; Vol. 2, No. 3, 1949, p. 30-32; No. 5, p. 60-63; No. 6, p. 77; Arctic. Journal of the Arctic Institute of North America, Vol. 1, No. 2, 1948, p. 137-38.]

Wireless communications in Canada are frequently disrupted by atmospheric disturbances, which cause intermittent fading and even complete inability 